Vol 2. No 2. Agustus 2018

ISSN 2580-5029

\title{
Pemanfaatan Daun Kelor (Moringa oleifera) Terhadap Pemulihan Struktur Pankreas Mencit Diabetik
}

\author{
Wanodya Ayu Chandradevi Kunharjitoㅁ, Muhammad Avesina', Dwi Puspita \\ Anggriyawanti1, Erlix Rakhmad Purnama1 ${ }^{*}$ \\ 1Universitas Negeri Surabaya, Surabaya, Indonesia \\ *erlixpurnama@unesa.ac.id
}

\begin{abstract}
Moringa oleifera is relatively easy to find in Indonesia and contains quercetin that are included in the flavonoid species, where they act as hypoglycemic agents. This study aims to determine the effect of Moringa oleifera extract on glucose, histopathology of pancreatic hyperglycemic mice. The method used in this research is Moringa oleifera leaf extract with concentration $42 \mathrm{mg} / \mathrm{kgBB}, 70 \mathrm{mg} / \mathrm{kgBB}$, and $98 \mathrm{mg} / \mathrm{kgBB}$, then intraperitoneal alloxan extract, application of Moringa oleifera extract, organ harvesting and pancreatic organ histology. The results showed that Moringa oleifera extract had an effect on decreasing glucose level and increasing the islet of Langerhans in diabetic mice. The most influential extract concentration was $98 \mathrm{mg} / \mathrm{kgBB}$. So it can be concluded that Moringa oleifera extract at concentration potentially as antihyperglicemic
\end{abstract}

Keywords: Moringa oleifera, diabetes mellitus, blood glucose, islet Langerhans

\begin{abstract}
ABSTRAK
Moringa oleifera tergolong mudah dijumpai di Indonesia dan mengandung senyawa quercetin yang termasuk dalam jenis flavonoid, dimana senyawa ini berperan sebagai agen hipoglikemik. Penelitian ini bertujuan untuk mengetahui pengaruh pemberian ekstrak Moringa oleifera terhadap kadar glukosa dan histopatologi pankreas mencit hiperglikemia. Metode yang digunakan pada penelitian ini yaitu ekstraksi daun Moringa oleifera dengan konsentrasi 42 $\mathrm{mg} / \mathrm{kgBB}, 70 \mathrm{mg} / \mathrm{kgBB}$, dan $98 \mathrm{mg} / \mathrm{kgBB}$, lalu penginduksian aloksan secara intraperitoneal, pengaplikasian ekstrak Moringa oleifera, pengambilan organ pankreas dan pembuatan histologi organ pankreas. Hasil penelitian menunjukkan bahwa Pemberian ekstrak Moringa oleifera berpengaruh pada penurunan kadar glukosa dan penambahan diameter pulau Langerhans pankreas mencit diabetes. Konsentrasi ekstrak yang paling berpengaruh adalah $98 \mathrm{mg} / \mathrm{kgBB}$. Maka dapat diambil simpulan bahwa ekstrak Moringa oleifera pada konsentrasi berpotensi sebagai antihiperglikemia.
\end{abstract}

Kata kunci: Moringa oleifera, diabetes melitus, glukosa darah, pulau Langerhans

\section{PENDAHULUAN}

Kurun waktu terakhir, dunia kesehatan semakin memprihatinkan.
Gaya hidup modern dan pola hidup tidak sehat ditengarai sebagai penyebab membludaknya penyakit-penyakit serius, salah satunya adalah diabetes melitus. 
Diabetes melitus merupakan penyakit tidak menular (Non-communicable desease) yang jumlah penderitanya semakin bertambah dari tahun ke tahun. Definisi dari diabetes melitus sendiri adalah suatu keadaan dimana tubuh tidak dapat memproduksi insulin atau tidak dapat menggunakan dengan optimal insulin yang dihasilkan oleh tubuh sehingga terjadi peningkatan kadar glukosa dalam darah melebihi normal yang disebut juga hiperglikemia (Anonim, 2017)

Menurut data International Diabetes Federation (IDF) 2015, jumlah diabetisi mencapai 415 juta jiwa dan diperkirakan akan terus meningkat pada tahun 2040 sekitar 642 juta jiwa (55\%). Indonesia berada pada peringkat ke-7 di bawah China, India, USA, Brazil, Rusia dan Mexico dari sepuluh negara dengan penyandang diabetes terbesar di seluruh dunia dengan penderitanya berjumlah sepuluh juta jiwa.

Organ yang paling berperan pada penyakit ini adalah pankreas, dimana organ tersebut memproduksi insulin untuk menstabilkan kadar glukosa darah. Berdasar penelitian Azhari Muslim, 2014, ukuran pulau Langerhans pankreas pada penderita diabetes melitus cenderung lebih kecil dibandingkan dengan pankreas normal. Hal ini diduga adanya penurunan massa sel $\beta$ pankreas, dimana diakibatkan oleh kematian sel karena efek toksik glukosa darah berlebih dalam waktu yang lama (Cnop et al., 2005)

Pada penelitian sebelumnya, Bahriyah dkk (2015) melaporkan bahwa Moringa oleifera tersebar melimpah di Kecamatan Tembelangan Kabupaten Sampang, Madura dengan jumlah tanaman tersebut diketahui 88 individu, yaitu Dusun Jemgelis 53\% (47 individu), Dusun Pelan 24\% (21 individu), dan Dusun Somber 23\% (20 individu). Faktor kemelimpahan dan kandungan senyawa yang dimiliki menunjang para peneliti untuk menemukan ramuan alami dalam langkah pencegahan dan pemulihan diabetes. Oleh karena itu diperlukan pengkajian lebih mendalam mengenai masalah tersebut.

\section{METODE PENELITIAN}

Tahap pertama adalah pembersihan kandang mencit berbentuk kubus berdinding kawat besi. Aklimatisasi hewan uji dalam lingkungan laboratorium selama satu minggu untuk penyesuaian lingkungannya. Selama observasi tujuh hari sebelum perlakuan kondisi sehat dengan aktivitas dan tingkah laku normal.

Pada rentan waktu aklimatisasi mencit, dilakukan proses ekstraksi daun Moringa oleifera. Pertama, dilakukan pengumpulan daun Moringa oleifera. Daun dicuci dan dikeringanginkan. Selanjutnya, dilakukan kering oven $\left(60^{\circ}\right.$ $70^{\circ} \mathrm{C}$ ) lalu dijadikan simplisia berupa serbuk. Setiap tahap dilakukan penimbangan. Kemudian proses maserasi dan ekstraksi etanol. Tahap terakhir ekstraksi adalah pengentalan ekstrak menggunakan alat Rotary Vacum Evaporator.

Setelah tujuh hari aklimatisasi, mencit sebanyak 15 ekor diukur dan dicatat kadar glukosa darah awal. Dilakukan induksi Aloksan dosis 175 $\mathrm{mg} / \mathrm{kgBB}$ secara interperitoneal kemudian diukur glukosa darah 48 jam setelah induksi.

Berikutnya, tahap pengaplikasian ekstrak yang dimulai pada hari ke-3 
setelah induksi Aloksan selama 21 hari dengan dosis ekstrak yang terbagi secara simple random sampling menjadi 5 kelompok, yaitu tersaji dalam tabel berikut:

Tabel 1. Perlakuan dan ulangan setiap kelompok mencit.

\begin{tabular}{|c|c|c|c|}
\hline \multirow{2}{*}{ Perlakuan } & \multicolumn{3}{|c|}{ Ulangan } \\
\cline { 2 - 4 } & 1 & 2 & 3 \\
\hline A & $\mathrm{A}_{1}$ & $\mathrm{~A}_{2}$ & $\mathrm{~A}_{3}$ \\
\hline B & $\mathrm{B}_{1}$ & $\mathrm{~B}_{2}$ & $\mathrm{~B}_{3}$ \\
\hline C & $\mathrm{C}_{1}$ & $\mathrm{C}_{2}$ & $\mathrm{C}_{3}$ \\
\hline D & $\mathrm{D}_{1}$ & $\mathrm{D}_{2}$ & $\mathrm{D}_{3}$ \\
\hline E & $\mathrm{E}_{1}$ & $\mathrm{E}_{2}$ & $\mathrm{E}_{3}$ \\
\hline
\end{tabular}

Keterangan:

A : Kontrol positif (tidak diinduksi Aloksan dan ekstrak Moringa oleifera)

B : Kontrol negatif (diinduksi Aloksan tetapi tidak diberi ekstrak Moringa oleifera)

C : Diinduksi Aloksan dan ekstrak Moringa oleifera $42 \mathrm{mg} / \mathrm{kgBB}$

D : Diinduksi Aloksan dan ekstrak Moringa oleifera $72 \mathrm{mg} / \mathrm{kgBB}$

E : Diinduksi Aloksan dan ekstrak

Moringa oleifera $98 \mathrm{mg} / \mathrm{kgBB}$

Tahap terakhir adalah pembuatan preparat histopatologi pankreas menggunakan metode parafin. Mencit ada masing-masing kelompok diambil secara gambling, kemudian dilakukan cervical dislocation dan pengambilan organ pankreas. Preparat diwarnai menggunakan Hematoxyline-eosin (HE), lalu dilakukan pengamatan jaringan pankreas mencit di bawah mikroskop.

\section{HASIL DAN PEMBAHASAN}

Berdasarkan penelitian yang telah dilakukan, ekstrak Moringa oleifera dapat memulihkan kadar glukosa darah dan berperan sebagai antihiperglikemia. Hasil kadar glukosa darah mencit setelah induksi alloxan disajikan dalam Gambar 4

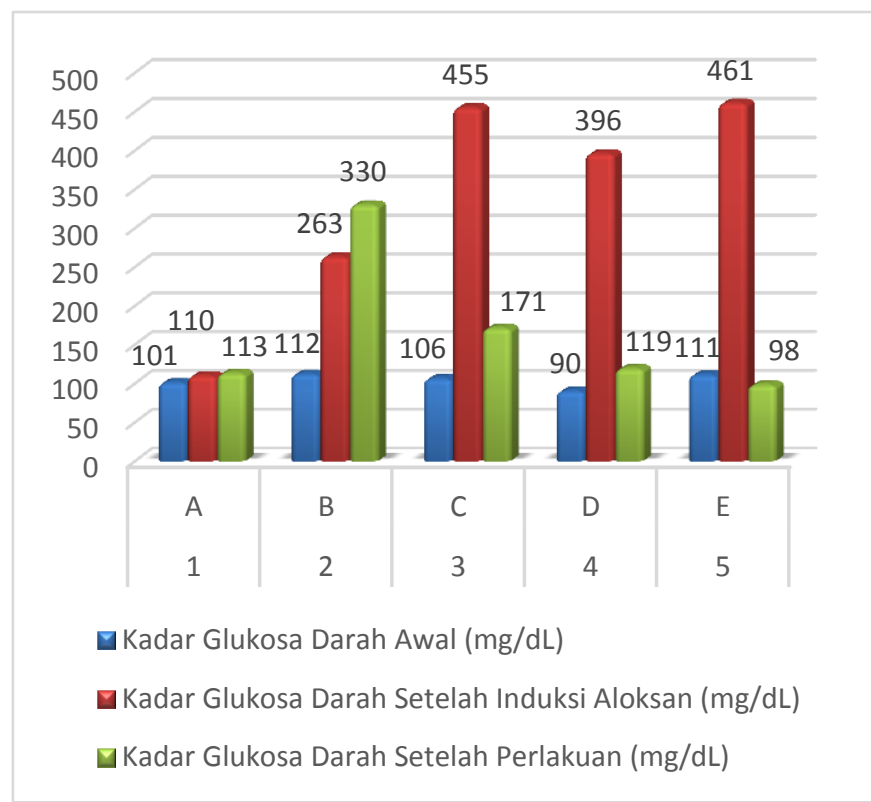

Gambar 1. Grafik Kadar Glukosa Darah Mencit Sebelum dan Sesudah Perlakuan

A (tanpa induksi aloksan dan ekstrak),

B (Induksi aloksan tanpa ekstrak),

C (induksi aloksan + ekstrak 42 $\mathrm{mg} / \mathrm{kgBB}$ ), D (Induksi aloksan + ekstrak $72 \mathrm{mg} / \mathrm{kgBB}$ ), dan E (Induksi aloksan + $98 \mathrm{mg} / \mathrm{kgBB}$ ).

Kadar glukosa darah normal mencit (Mus musculus) adalah 75-140 $\mathrm{mg} / \mathrm{dL}$. Dari tabel diatas menunjukkan bahwa kadar glukosa darah mencit sebelum diinduksi aloksan masih dalam kisaran normal. Setelah induksi aloksan menjadi jauh diatas normal, sehingga setiap kelompok yang telah diinduksi aloksan tersebut menunjukkan kondisi diabetes melitus. Setelah 21 hari pemberian ekstrak Moringa oleifera, 
kadar glukosa mengalami penurunan yang berarti.

Berdasarkan tabel diatas, dapat diperoleh data pada perlakuan $\mathrm{C}$, glukosa darah turun hingga $62 \%$, pada perlakuan D glukosa darah turun hingga 69\%, dan perlakuan E kadar glukosa darah turun hingga 78\%. Hal ini mengindikasikan bahwa senyawa flavonoid terutama quercetin (senyawa terbesar) dapat memulihkan kadar glukosa dalam darah.

Senyawa aktif pada daun kelor antara lain $\mathrm{Ca}^{2+}, \mathrm{K}^{+}$, wax, alkaloid, quercetin dan kaempferol. Quercetin dan kaempferol adalah flavonoid, senyawa dengan gugus hidroksil fenolik dengan aksi antioksidan yang memiliki potensi penggunaan terapeutik. Penelitian sebelumnya menyatakan bahwa quercetin merupakan inhibitor enzim $\alpha$-amilase yang berfungsi dalam pemecahan karbohidrat. Diantara jenis flavonol, subkelas flavonoid, quercetin berpotensi menjadi inhibisi enzim terkuat (Piparo dkk, 2008). Dengan adanya inhibisi pada enzim ini, proses pemecahan dan absorbsi karbohidrat akan terganggu, sehingga dapat menurunkan kadar glukosa darah pada hiperglikemia.

Dalam penelitian terdahulu terbukti bahwa kuersetin dapat mengontrol kadar glukosa darah puasa dan hiperglikemia postprandial. Mekanisme utama penurunan kadar glukosa darah diperantai oleh aktivitas inhibisi pada enzim alfa-glukosidase, sehingga absorbsi dari glukosa dapat diperlambat (Jadhav \& Puchchakayala, 2012).

Penderita DM ditandai dengan sering buang air kecil terutama pada malam hari (poliuria), sering haus (polidipsia), dan rasa lapar yang berlebihan (polifagia) (Utami, 2003:13). Sedangkan menurut Fox dan Anne (2010:24), gejala pada penderita diabetes seperti rasa haus yang berlebih dan menurunnya berat badan secara drastis. Bila kadar glukosa darah naik diatas 180 $\mathrm{mg} / \mathrm{dl}$, ginjal tidak dapat menahan sebagian glukosa yang ada pada darah sehingga glukosa tersebut dibuang bersama dengan urine. Kadar glukosa pada urin yang tinggi dan menarik banyak air (daya osmotik gula), akibat penarikan air yang terlalu banyak, volume urin berlebihan, oleh sebab itu penderita DM sering kencing (poliurea). Keadaan tersebut akan mengganggu neraca air di dalam tubuh, yang akhirnya dimanifestasikan oleh rasa haus terus menerus (polidipsia).

Parameter akhir pada penelitian ini ialah pengamatan histologi preparat pankreas pada masing-masing perlakuan. Adapun hasil pengamatan terhadap pulau Langerhans pankreas disajikan pada Gambar 2. 


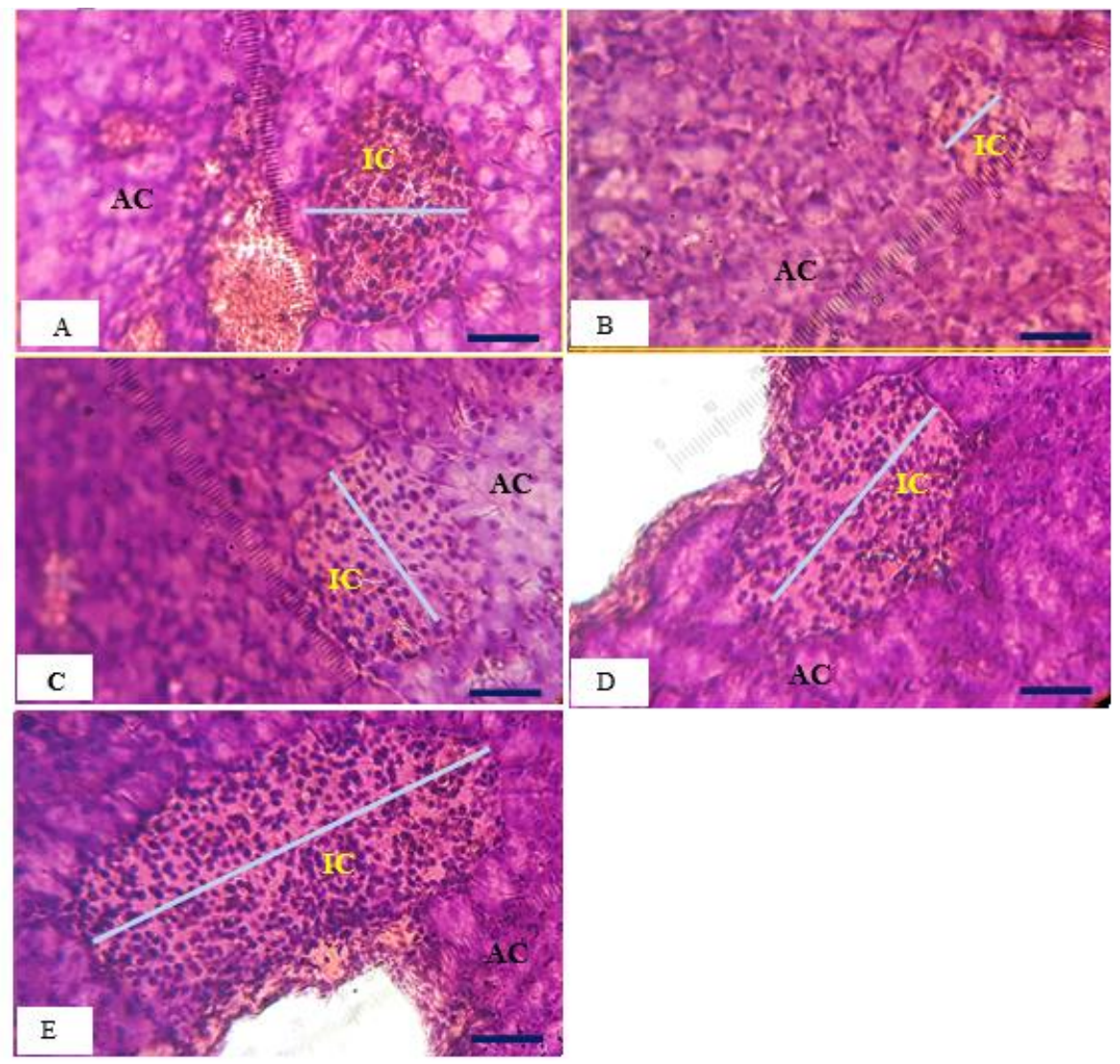

Gambar 2. Histologi Pulau Langerhans Pankreas Masing-masing Perlakuan dengan Perbesaran 400x

dA (tanpa induksi aloksan dan ekstrak): 30,5 $\mu \mathrm{m}, \mathrm{dB}$ (Induksi aloksan tanpa ekstrak): $15 \mu \mathrm{m}, \mathrm{dC}$ (induksi aloksan + ekstrak $42 \mathrm{mg} / \mathrm{kgBB}$ ): 27,5 $\mu \mathrm{m}$, D (Induksi aloksan + ekstrak $72 \mathrm{mg} / \mathrm{kgBB}: 37,5 \mu \mathrm{m}$ ), dan dE

(Induksi aloksan + $98 \mathrm{mg} / \mathrm{kgBB}$ ): $50 \mu \mathrm{m}$. Ket: d: diameter; IC: Islet Cells; AC: Acinar Cells.

Sel-sel yang terdapat pada diameter pulau Langerhans mencit pankreas mengalami banyak perubahan setelah mengalami diabetes melitus. Perubahan ini dapat terjadi baik secara kuantitatif, misalnya pengurangan jumlah atau ukuran, maupun secara kualitatif, antara lain nekrosis, amyloidosis, dan degenerasi.

Berdasarkan pengamatan histologi pulau Langerhans pankreas, diameter pulau masing-masing perlakuan berbedabeda Adanya penyempitan ukuran pulau Langerhans juga menjadi akibat dari diabetes melitus. Penyempitan ini dapat dilihat dari perbedaan sangat signifikan normal (KN) dan mencit diabetes melitus (KP). Perlakuan kelompok A sebagai kontrol negatif, yaitu tanpa induksi aloksan dan ekstrak, memiliki diameter pulau $\pm 30,5 \mu \mathrm{m}$. Pada kontrol positif, yaitu induksi aloksan tanpa pemberian ekstrak Moringa oleifera hanya berdiameter $\pm 15 \mu \mathrm{m}$. Hal ini menunjukkan bahwa terdapat penyempitan atau degenerasi sel pada pulau Langerhans mencit diabetes.

Hasil pemberian ekstrak Moringa oleifera $42 \mathrm{mg} / \mathrm{kgBB}, 72 \mathrm{mg} / \mathrm{kgBB}$, dan 98 $\mathrm{mg} / \mathrm{kgBB}$ menunjukkan adanya 
penambahan diameter pulau Langerhans mencit diabetes melitus, yaitu masingmasing memiliki diameter 27,5 $\mu \mathrm{m}, 37,5$ $\mu \mathrm{m}$, dan $50 \mu \mathrm{m}$. Penambahan diameter pulau Langerhans dipengaruhi oleh kerja senyawa aktif pada daun Moringa oleifera yaitu senyawa flavonoid. Penelitian Tende dkk. menunjukkan bahwa flavonoid mempunyai efek hipoglikemik, meskipun efek hipoglikemik terpenoid tampak terlibat dalam menstimulasi sel $\beta$ pankreas dan selanjutnya meningkatkan sekresi insulin.
Adanya induksi Aloksan dapat menghambat produksi insulin melalui penghambatan jalur glukokinase, sensor glukosa pada sel beta, dan hal ini menyebabkan diabetes dependen insulin melalui kemampuannya untuk membentuk ROS (Reactive Oxygen Species). Aloksan sebagai model senyawa toksisitas sel beta yang termediasi oleh ROS, adalah agen penyebab paling besar yang mengakibatkan adanya kematian sel beta pada tipe II diabetes seperti pada Gambar 3.
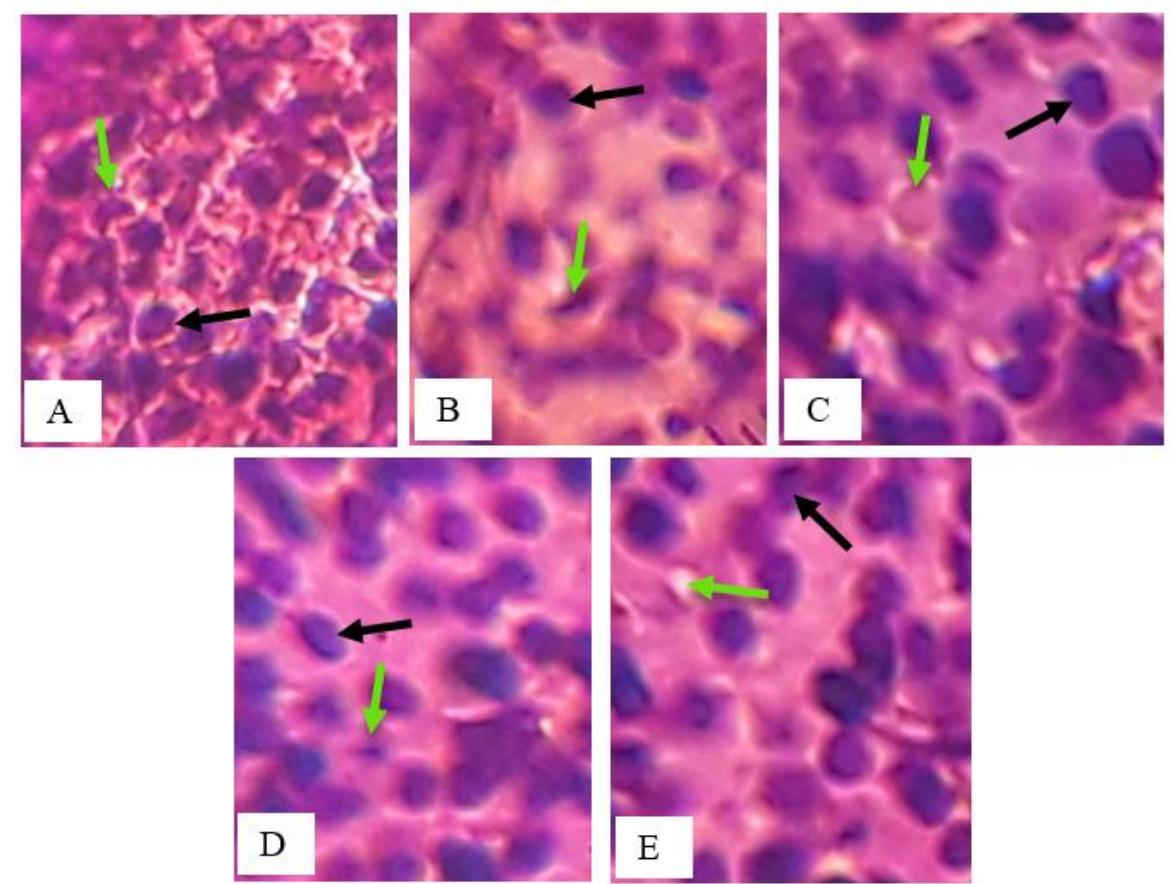

Gambar 3. Sel Beta Pankreas Normal dan Mengalami Nekrosis

A (tanpa induksi aloksan dan ekstrak), B (Induksi aloksan tanpa ekstrak), C (induksi aloksan + ekstrak 42 mg/kgBB), D (Induksi aloksan + ekstrak $72 \mathrm{mg} / \mathrm{kgBB}, \mathrm{E}$ (Induksi aloksan + $98 \mathrm{mg} / \mathrm{kgBB})$. Ket: $>$ : Sel

Nekrosis, $\nearrow$ : Sel Normal

Kandungan flavonoid terbesar artery). Sehingga dapat menangkal pada daun kelor ialah Quercetin. Quercetin bekerja dengan menghambat produksi LPS (Lipopolysaccharide) atau sitokin Macrophages Like Celldengan meregulasi ekspresi protein iNOS dan transkripsi MRA (Mesenteric Resistance terbentuknya ROS sekaligus mencegah adanya kematian sel beta pulau Langerhans pankreas, bahkan Quercetin meregenerasi sel beta pankreas yang telah terdegradasi. 
Biotropic 2018. 2 (2): 85 - 92

Pemanfaatan Daun Kelor (Moringa oleifera) Terhadap Pemulihan Struktur Pankreas Mencit Diabetik

Banyak faktor yang menyebabkan kerusakan sel beta pankreas. Faktor tersebut di antaranya faktor genetik, infeksi oleh bakteri, faktor nutrisi, zat diabetogenik, dan radikal bebas (stres oksidatif). Senyawa aloksan merupakan salah satu zat diabetogenik yang bersifat toksik, terutama terhadap sel beta pankreas, dan apabila diberikan kepada hewan coba seperti tikus dapat menyebabkan hewan coba tikus menjadi diabetes. Kerusakan sel beta pankreas menyebabkan tubuh tidak bisa menghasilkan insulin sehingga menyebabkan kadar glukosa darah meningkat (terjadi keadaan hiperglikemia). Kondisi hiperglikemia menurut Robertson et al. (2003) dapat menghasilkan pembentukan spesies oksigen reaktif (ROS=reactive oxygen species). ROS yang berlebihan dapat menyebabkan stres oksidatif dan dapat memperparah kerusakan sel beta pankreas.

\section{KESIMPULAN}

Berdasarkan penelitian yang telah dilakan dapat diperoleh kesimpulan bahwa ekstrak Moringa oleifera berpengaruh pada glukosa darah dan histopatologi pankreas mencit diabetes. Hasil menunjukkan bahwa ekstrak dengan konsentrasi 98 mg/kgBB mampu memberikan pengaruh paling besar dalam menurunkan kadar glukosa darah dan mampu meregenerasi sel beta pankreas jika dibandingkan dengan konsentrasi lainnya.

\section{DAFTAR PUSTAKA}

Bahriyah, Izzatul; Hayati, Ari; Zayadi, Hasan. Tanaman Kelor (Moringa oleifera) di desa Somber Kecamatan Tambelangan Kabupaten Sampang Madura. Malang: Unisma.

Cnop, M., N. Welsh, J. C. Jonas, A. Jorns, S. Lenzen, and D. L. Eizirik. 2005. Pancreatic $\beta$-cell Death in Type 1 and Type 2 Diabetes - Many Differences, Few Similarities, Diabetes, 54,97-107.

Elsner, M; Guldbakke, B; Tiedge, M; Munday, R. 2000. Relative Importance of Transport and Alkilation for Pancreatic Beta-Cell Toxicity of Streptozotocin. Vol 43, Issue 12, pp 1528-1533.

Fox, Charles \& Anne Kilvert. 2010. Bersahabat dengan Diabetes Tipe 1. Niaga Swadaya, Jakarta.

Franson, R.D. 1992. Anatomi dan Fisiologi Ternak Edisi ke-4. Gadjah Mada University Press, Yogyakarta.

Gastelu, D. 2004. All About Bioflavonoids. Online

(http://www.supplementfacts.co m diakses pada tanggal 1 Oktober 2017).

Halim, J. 1990. Atlas Praktikum Histologi. $4^{\text {th }}$ ed. EGC, Jakarta. p:44.

Jadhav R, Puchchakayala G. 2012. Hypoglicemic and Antidiabetic Activity of Flavonoids: Boswellic Acid, Ellagic Acid, Quercetin, Rutin On Streptozotocin-Nicotinamide Induced Type 2 Diabetic Rats. Int. J. Pharm Pharmaceut Sci; 2(2):2516.

Junqueira, L.C. 1995. Histologi Dasar. $1^{\text {th }}$ ed. EGC, Jakarta. pp: 314-6. 
Muslim, Azhari. 2014. Hubungan Jumlah Leukosit Dengan Kadar Mikroalbumin Urin Pada Penderita Diabetes Melitus. Vol X, No. 1.

Pathak, R. D; Tran, T; Basa, A.L.P. 2004. Metastatic Insulinoma Case Report and Review of the Literature. Southern Medical Journal.

Piparo. 2008. Flavonoids for Controlling Strarch Digestion: Structural Requirements for Inhibiting Human $\alpha$-amylase.

Robertson RP, Harmon J, Tran PO, Tanaka Y, Takahashi H. 2003. Glucose toxicity in $\beta$-cells: Type 2 Diabetes, Good Radicals Gone Bad, and the Glutathione Connection. Diabetes. Vol 52. Pg: 581-587.

Sihem Berdja, Leila Smail, Boualem Saka, Samia Neggazi, El-mehdi Haffaf,
Yasmina Benazzoug, Ghouti Kacimi, Lynda Boudarene, and Souhila Aouichat Bouguerra. 2016. Glucotoxicity Induced Oxidative Stress and Inflammation In Vivo and In Vitro in Psammomys obesus: Involvement of Aqueous Extract of Brassica rapa rapifera. Vol. 2016, Article ID 3689208, Page 14.

Subowo. 1992. Histologi Umum. $2^{\text {th }}$ ed. bumi aksara, Jakarta. pp: 38-9.

Tende JA, Ezekiel I, Dikko AAU, Goji ADT. Effect of ethanolic leaves extract of moringa oleifera on blood glucose levels of streptozotocin-induced diabetics and normoglycemic wistar rats. $\mathrm{Br} \mathrm{J}$ Pharm Toxicol. 2011;2(1):1-4.

Utami, Prapti. 2003. Tanaman Obat untuk Mengatasi Diabetes Mellitus. Agromedia Pustaka, Tanggerang. 